\title{
FAKTOR-FAKTOR YANG MEMPENGARUHI RETURN SAHAM PERUSAHAAN FARMASI YANG TERDAFTAR DI BURSA EFEK INDONESIA
}

\author{
Muhammad Nur Mufid \\ Universitas Jenderal Soedirman, Purwokerto, Indonesia \\ Email: mufidsantri99@gmail.com
}

\begin{abstract}
This study aims to examine the relationship between debt to equity and systematic risk on stock returns of pharmaceutical companies listed on the Indonesian stock exchange. The object of this research is a pharmaceutical company listed on the Indonesia Stock Exchange (IDX) with the financial reporting period of 2014-2017. The sampling technique in this study was purposive sampling and obtained eight samples. The test method used in this research is multiple regression analysis method. The results showed that the debt ratio (DER) had no effect on stock returns, while the systematic risk (BETA) had a significant effect on stock returns. The implication of this research is that it provides an understanding for investors in making investment decisions to consider the fundamental analysis of financial information in estimating the stock returns that will be received. In addition, investors must also consider and pay attention to the risks that will be obtained which will certainly affect stock returns.
\end{abstract}

Keywords: stock returns, debt to equity ratio, systematic risk

\section{ABSTRAK}

Penelitian ini bertujuan untuk menguji hubungan antara debt to equity dan risiko sistematis terhadap return saham perusahaan farmasi yang terdaftar di bursa efek Indonesia. Objek penelitian ini adalah perusahaan farmasi yang terdaftar di Bursa Efek Indonesia (BEI) dengan periode laporan keuangan tahun 2014-2017. Teknik pengambilan sampel pada penelitian ini adalah purposive sampling dan diperoleh delapan sampel. Metode pengujian yang digunakan dalam penelitian ini adalah metode analisis regresi berganda. Hasil penelitian menunjukkan, bahwa rasio utang (DER) tidak memberikan pengaruh terhadap return saham, sedangkan risiko sistematis (BETA) memberikan pengaruh signifikan terhadap return saham. Implikasi dalam penelitian ini adalah memberikan pemahaman bagi para investor dalam melakukan pengambilan keputusan untuk investasi harus mempertimbangkan analisa fundamental informasi keuangan dalam memperkirakan return saham yang akan diterima. Selain itu, para investor juga harus mempertimbangkan dan memperhatikan risiko-risiko yang akan diperoleh yang tentunya akan mempengaruhi return saham.

Kata kunci: return saham, debt to equity ratio, risiko sistematis

\section{KETERANGAN ARTIKEL}

Riwayat Artikel: diterima: 3 Februari 2020; direvisi: 15 Mei 2020; disetujui: 27 Juni 2020

Klasifikasi JEL: H54

Cara Mensitasi: Mufid, Muhammad N. (2020). Determinasi DER dan Risiko Sistematis terhadap Return Saham Perusahaan Farmasi yang Terdaftar di Bursa Efek Indonesia. JIAFE (Jurnal IImiah Akuntansi Fakultas Ekonomi), 6(1), 83-92. https://doi.org/10.34204/jiafe.v6i1.1820

Copyright C2020. JIAFE (Jurnal IImiah Akuntansi Fakultas Ekonomi) Universitas Pakuan

\section{PENDAHULUAN}

Untuk menilai kondisi keuangan suatu perusahaan, investor akan melakukan analisis laporan keuangan berupa penilaian kinerja keuangan perusahaan (Arista, 2012). Analisis yang dilakukan bertujuan untuk membuat kebijakan terkait dengan investasinya. Analisis tersebut dapat dilakukan secara fundamental dan secara teknis, secara fundamental, investor dapat menilai struktur modal, kemampuan perusahaan dlaam menghasilkan laba dan lainnya. Kebijakan investor akan 
terkait langsung dengan return dari investasinya.

Industri farmasi sebagai salah satu industri yang terdaftar di Bursa Efek Indonesia (BEI) telah tumbuh rata-rata 20,6\% per tahun 2011-2016 (Arvirianty, 2017). Berdasarkan data realisasi investasi dari Badan Koordinasi Penanaman Modal (BKPM), sub sektor farmasi memberikan kontribusi sekitar $27 \%$ dari total pangsa pasar farmasi ASEAN sehingga farmasi cukup mendominasi di penanaman modal dalam negeri dan penanaman modal asing.

Pertumbuhan industri farmasi dipengaruhi dengan peningkatan kebutuhan masyarakat akan obat-obatan, kesadraan masyarakat akan kesehatan, serta peningkatan pengeluaran kesehatan terhadap Gross Domestic Product (GDP) perkapita. Di Indonesia terdapat sekitar 239 perusahaan farmasi yang sebagian besar terdapat di Jawa Barat (39\%), Jawa Timur (20\%), dan DKI Jakarta (15\%). Perusahaan farmasi besar nasional juga terdaftar di Bursa Efek Indonesia (BEI) terdiri dari 10 perusahaan dan 2 diantaranya merupakan Badan Usaha Milik Negara (BUMN) yaitu PT Kimia Farma (Persero) Tbk dan PT Indofarma (Persero) Tbk.

Sejak diberlakukannya regulasi mengenai jaminan sosial untuk masyarakat yang dikelola oleh Badan Penyelenggara Jaminan Sosial (BPJS), semakin mendorong peningkatan pada industry farmasi. Semakin banyak masayrakat yang memiliki Kartu Jaminan Kesehatan (JKN), maka produksi obatobatan pada industri farmasi mengalami peningkatan. Selain itu, meningkatnya pemegang JKN juga meningkatkan persaingan dalam industry farmasi akrena perusahaan farmais semakin berupaya meningkatkan produksi obat-obatnya khususnya obat generic. Hal tersebut seiring dengan permintaan dari adanya program JKN.

Penelitian ini dilakukan dengan menggunakan sampel perusahaan farmasi karena masih kurangnya penelitian yang menggunakan sampel perusahaan tersebut. Perusaahaan farmasi merupakan perusahaan yang memiliki pangsa pasar yang besar di Indonesia.

Sugiarto (2011) menyatakan bahwa DER mempengaruhi return saham, yaitu ketika DER yang tinggi akan cenderung kurang menarik bagi investor. Hal tersebut karena dengan semakin tinggi tingkat utang akan mempengaruhi beban bunga yang harus dibayarkan oleh perusahaan. Semakin besar beban perusahaan cenderung menurunkan kinerja perusahaan jika dilihat dari laba. Namun demikian selanjutnya menurut Sugiarto (2011), berdasarkan balancing theory perusahaan yang memiliki struktur utang tinggi juga dapat menunjukkan kemampuan perusahaan untuk menyeimbangkan manfaat dengan biaya yang ditimbulkan dari utang. Penelitian lain yang menunjukkan adanya pengaruh antara DER dan variabel beta, yaitu antara lain Bandhari (1998), Sudarto, dkk, 1999), Zulbahridar dan Jonius (2002), Arista (2012), Yunina (2013), dan Supriyono (2016).

\section{KAJIAN LITERATUR DAN PENGEMBANGAN HIPOTESIS \\ Return saham}

Tingkat pengembalian (return) merupakan salah satu faktor yang memotivasi investor berinteraksi dan juga merupakan imbalan atas keberanian investor dalam menanggung risiko atas investasi yang dilakukannya (Tandelilin, 2010). Return dapat juga disebut sebagai keuntungan yang diperoleh oleh perusahaan, individu, dan institusi dari hasil kebijakan investasi yang dilakukannya (Fahmi, 2012).

Return saham yang tinggi akan menunjukan kinerja keuangan perusahaan yang baik. Sehingga tingkat pengembalian atas investasi yang ditanamkan investor akan semakin besar. Berdasarkan hal tersebut, hal ini akan menarik perhatian investor dan meningkatkan permintaan saham (Jogiyanto, 2014). Hal tersebut karena return merupakan hasil yang diperoleh dari investasi yang dapat berupa return realisasian yang sudah terjadi atau return ekspektasian yang belum terjadi tetapi yang diharapkan akan terjadi di masa 
mendatang. Return saham diukur dengan formula sebagai berikut:

$$
R i=\frac{(P t-P t-1)}{(P t-1)}
$$

Di mana:

$\mathrm{Ri}=$ Return saham,

Pt = Harga saham periode $t$, dan

Pt-1 = Harga saham periode $\mathrm{t}-1$

\section{Debt to Equity Ratio (DER)}

Debt to equity ratio (DER) merupakan rasio utang terhadap modal. Rasio ini mengukur seberapa jauh perusahaan dibiayai oleh utang. DER diukur menggunakan formula sebagai berikut:

$$
D E R=\frac{\text { Total debt }}{\text { Total Equity }}
$$

Semakin tinggi rasio DER menggambarkan gejala yang kurang baik bagi perusahaan. Peningkatan utang pada gilirannya akan mempengaruhi besar kecilnya laba bersih yang tersedia bagi para pemegang saham termasuk dividen yang diterima karena kewajibannya untuk membayar utang lebih diutamakan daripada pembagian dividen (Sartono, 2001). Pemilihan alternatif penambahan modal yang berasal dari utang memiliki keunggulan yaitu melalui utang bunga mengurangi pajak sehingga beban utang rendah (Prasetyo, dkk., 2012).

Debt to equity ratio mewakili solvabilitas digunakan untuk mengukur tingkat leverage yang menunjukkan kemampuan modal sendiri perusahaan untuk memenuhi seluruh kewajibannya. Semakin besar jumlah utang yang digunakan untuk struktur modal perusahaan, maka akan semakin besar jumlah kewajibannya.

H1: Debt equity ratio berpengaruh terhadap return saham

\section{Risiko Sistematis (Beta)}

Risiko sistematis atau risiko yang tidak dapat didiversifikasi atau dihindarkan disebut juga dengan risiko pasar yang berkaitan dengan kondisi yang terjadi di pasar secara umum, misalnya perubahan dalam perekonomian secara makro, risiko tingkat bunga, risiko politik, risiko inflasi, risiko nilai tukar dan risiko pasar. Risiko ini mempengaruhi semua perusahaan dan karenanya tidak bisa dihilangkan dengan diversifikasi. Parameter yang digunakan dalam mengukur risiko ini adalah beta. Beta suatu sekuritas dapat dihitung dengan titik estimasi yang menggunakan data historis maupun estimasi secara subjektif. Beta historis dapat dihitung dengan menggunakan data historis berupa data pasar (return sekuritas dan return pasar), yaitu dengan formula sebagai berikut.

$$
\beta=\frac{N \sum X Y-\left(\sum X\right)\left(\sum Y\right)}{N \sum X^{2}-\left(\sum X\right)^{2}}
$$

Keterangan:

$\mathrm{X}=$ Return pasar $(\mathrm{Rm})$

$\mathrm{Y}=$ Return saham (Ri)

$\mathrm{N}=$ Jumlah data

$\beta=$ Beta saham

Selain itu Scott dkk., (2000) menyatakan bahwa Beta mengukur volatilitas saham relatif terhadap rata-rata saham. Beta merupakan sensitivitas return saham terhadap return on portofolio pasar (Brealey, dkk., 2001). Beta juga dapat disebut sebagai sejumlah risiko sistematis menyajikan aset berisiko tertentu relatif terhadap aset berisiko rata-rata (Ross, dkk.,2003) Dapat disimpulkan bahwa beta adalah pengukur volatilitas suatu risiko sistematis pada sekuritas. Risiko sistimatis atau beta merupakan satu-satunya faktor risiko yang relevan untuk mengukur tingkat keuntungan yang diharapkan dari suatu investasi. Arah pengaruh beta terhadap return adalah positif yang berarti bahwa semakin besar risiko suatu investasi semakin besar pula return yang disyaratkan oleh investor. 
Beta saham sebagai pengukuran risiko yang berasal dari hubungan antara tingkat keuntungan suatu saham dengan pasar (Husnan, 2005). Beta adalah ukuran volatilitas, atau risiko sistematis relatif dimana volatilitas merupakan fluktuasi dari return suatu sekuritas dalam suatu periode tertentu (Jones, 2000). Jika fluktuasi return sekuritas secara statistik mengikuti fluktuasi return pasar, maka beta dari sekuritas tersebut bernilai 1 . Misalnya apabila return pasar naik sebesar $5 \%$, maka investor akan menghargapkan kenaikan return sekuritasnya sebesar $5 \%$ pula.

H2: Beta berpengaruh terhadap return saham

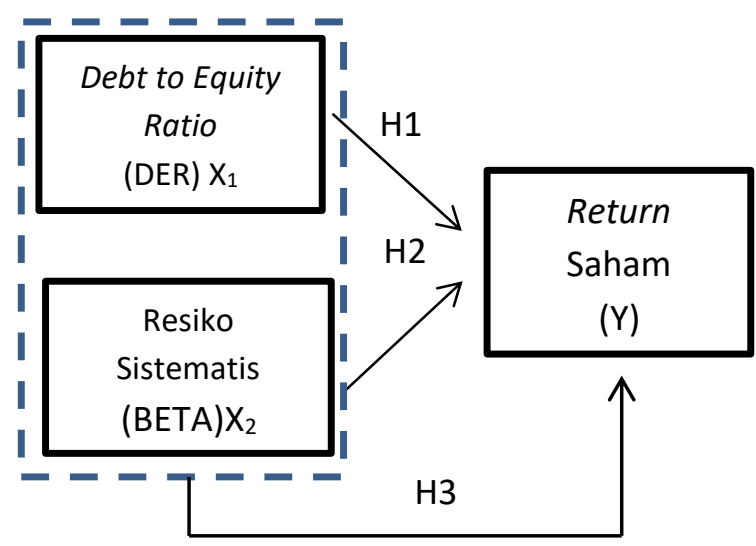

Gambar 1. Kerangka Pemikiran

Debt to Equity Ratio, Beta, dan Return Saham Nilai DER yang cukup tinggi menunjukkan bahwa perusahaan tersebut memiliki keharusan untuk membayar kewajiban yang tinggi. Semakin tinggi nilai DER akan cenderung menurunkan return saham. Hal tersebut terkait dengan beban bunga yang harus dibayarkan perusahaan yang dapat menurunkan laba perusahaan dan selanjutnya mempengaruhi pembagian deviden kepada pemegang saham. Selain itu, DER mempengaruhi investor yang akan menganggap semakin tinggi DER menunjukkan perusahaan tidak mampu membiayai kegiatan operasionalnya dengan modal sendiri sehingga harus menggunakan utang. Hal ini terkait dengan struktur modal perusahaan.

Selain itu, faktor yang mempengaruhi return saham adalah beta saham. Pertimbangan suatu investasi akan selal terkait dengan return dan risiko merupakan dua hal yang tidak terpisah. Return dan risiko mempunyai hubungan yang positif, semakin besar risiko yang harus ditanggung, semakin besar return yang harus dikompensasikan (Jogiyanto, 2014). Dengan demikian, DER dan Beta secara simultan dapat mempengaruhi return saham.

H3: DER dan Beta secara simultan mempengaruhi return saham.

\section{METODE PENELITIAN}

Populasi dan Sampel

Populasi yang digunakan dalam penelitian ini adalah semua perusahaan yang terdaftar di Bursa Efek Indonesia (BEI), sedangkan sampel penelitian ini diambil dengan teknik purposive sampling. Kriteria pengambilan sampel adalah perusahaan sub sektor farmasi yang tercatat dan tidak pernah delisting di Bursa Efek Indonesia pada periode tahun 2014-2017, serta perusahaan yang menerbitkan laporan keuangan dalam satuan rupiah untuk periode yang berakhir pada tanggal 31 Desember pada tahun 2014 - 2017 secara berturut-turut dengan tujuan komparabilitas yang baik.

Berdasarkan kriteria di atas, sampel yang diambil dalam penelitian ini berjumlah 8 perusahaan dengan periode pengamatan 4 periode (tahun 2014-2017). Jadi jumlah data dalam penelitian ini menjadi 32 data. 
Tabel 1. Sampel Perusahaan

\begin{tabular}{ccl}
\hline No. & Kode Perusahaan & \multicolumn{1}{c}{ Nama Perusahaan } \\
\hline 1. & DVLA & PT Darya Varia Laboratoria, Tbk \\
\hline 2. & INAF & PT Indofarma, Tbk \\
\hline 3. & KAEF & PT Kimia Farma, Tbk \\
\hline 4. & KLBF & PT Kalbe Farma, Tbk \\
\hline 5. & MERK & PT Merck, Tbk \\
\hline 6. & PYFA & PT Pyridam Farma, Tbk \\
\hline 7. & SIDO & PT Sido Muncul, Tbk \\
\hline 8. & TSPC & PT Tempo Scan Pasific, Tbk
\end{tabular}

\section{Jenis dan Metode Pengumpulan Data}

Jenis data yang digunakan dalam penelitian ini adalah data sekunder. Metode pengumpulan data pada penelitian ini yaitu dengan dengan mengunduh laporan keuangan perusahaan yang terdaftar di Bursa Efek Indonesia (BEI).

\section{Metode Analisis Data}

Analisis data menggunakan analisis regresi berganda yaitu pengujian statistik yang digunakan untuk mengetahui pengaruh dua variabel atau lebih terhadap variabel dependen. Pada penelitian ini model regresi yang digunakan adalah sebagai berikut.

$$
Y=a+b 1 X_{1}+b 2 X_{2}+e
$$

$$
\begin{aligned}
& \text { Keterangan: } \\
& \mathrm{Y}=\text { return saham } \\
& \mathrm{a}=\text { kontanta } \\
& \mathrm{b} \quad=\text { koefisien regresi } \\
& \mathrm{X}_{1}=\text { Debt to Equity Ratio (DER) } \\
& \mathrm{X}_{2} \quad=\text { Resiko Sistematis (Beta) }
\end{aligned}
$$

\section{HASIL DAN PEMBAHASAN}

Hasil Penelitian

\begin{tabular}{|c|c|c|c|c|c|c|}
\hline & \multirow[t]{2}{*}{ Model } & \multicolumn{2}{|c|}{$\begin{array}{l}\text { Unstandardized } \\
\text { Coefficients }\end{array}$} & \multirow{2}{*}{$\begin{array}{c}\text { Standardized } \\
\text { Coefficients } \\
\text { Beta }\end{array}$} & \multirow[t]{2}{*}{$t$} & \multirow[t]{2}{*}{ Sig. } \\
\hline & & B & Std. Error & & & \\
\hline & (Constant) & 1312,925 & 441,292 & & 2,975 & 0,006 \\
\hline \multirow[t]{2}{*}{1} & DER & 1,386 & 1,813 & 0,122 & 0,765 & 0,451 \\
\hline & BETA & $3,236 \mathrm{E}-005$ & 0,000 & 0,509 & 3,184 & 0,003 \\
\hline
\end{tabular}

Hasil penelitian berupa hasil pengujian uji $t$ untuk mengetahui pengaruhi variabel dependen dan independen ditunjukkan pada tabel berikut ini.

Tabel 2. Hasil Uji t

Coefficients $^{\mathrm{a}}$ 
Berdasarkan hasil pengujian data menunjukkan bahwa variabel debt to equity tidak berpengaruh terhadap return. Hal tersebut karena nilai signifikansi DER sebesar 0,451 yang lebih besar dari 0,05 sehingga hipotesis satu ditolak.

Selain itu, variabel BETA memiliki pengaruh secara parsial terhadap return saham. Berdasarkan tabel variabel BETA memiliki signifikansi kurang dari 0,05 sehingga hipotesis dua diterima.

Selain pengujian secara parsial, berikut disajikan tabel hasil pengujian simultan untuk kedua variabel.

Tabel 3. Hasil Uji F

ANOVA $^{a}$

\begin{tabular}{rlrrrrr}
\hline & Model & $\begin{array}{l}\text { Sum of } \\
\text { Squares }\end{array}$ & df & Mean Square & F & Sig. \\
\hline & Regression & 2113024,296 & 2 & 1056512,148 & 5,192 & $0,012^{\text {b }}$ \\
\hline 1 & Residual & 5901602,173 & 29 & 203503,523 & & \\
\hline & Total & 8014626,469 & 31 & & & \\
\hline
\end{tabular}

a. Dependent Variable: RETURN SAHAM

b. Predictors: (Constant), BETA, DER

Berdasarkan tabel diatas, kedua variabel independen secara simultan berpengaruh terhadap variabel dependen. Hal tersebut ditunjukkan dengan nilai signifikansi sebesar 0,012 yang lebih besar dari 0,05 sehingga disimpulkan bahwa hiptesis tiga diterima, yaitu variabel DER dan BETA berpengaruh secara simultan terhadap Return Saham.

Berikut disajikan tabel hasil pengujian $\mathrm{R}$ square.

Tabel 4. Koefisien Determinasi

Summary

\begin{tabular}{|l|l|l|l|l|}
\hline Model & R & R Squre & $\begin{array}{l}\text { Adjusted R } \\
\text { Square }\end{array}$ & $\begin{array}{l}\text { Std. Error of } \\
\text { The Estimate }\end{array}$ \\
\hline 1 & $0,513^{\mathrm{a}}$ & 0,264 & 0,213 & 451,11365 \\
\hline
\end{tabular}

a. Predictors: (Constant), BETA, DER

Berdasarkan dari tabel di atas, nilai adjusted $R$ Square yaitu sebesar $21,3 \%$. Hal tersebut menunjukkan bahwa besarnya pengaruh variabel DER dan BETA terhadap return saham adalah $21,3 \%$, sedangkan sisanya $(78,7 \%)$ dipengaruhi oleh variabel lain diluar penelitian.

\section{Pembahasan}

\section{Debt to Equity Ratio dan return saham}

Hasil penelitian yang menunjukkan tidak adanya pengaruh variabel debt to equity ratio (DER) terhadap return saham mengindikasikan adanya pertimbangan yang berbeda antar investor dalam mempertimbangkan DER sebagai keputusan berinvestasi.

Teori signaling menjelaskan bahwa dimana perusahaan yang meningkatkan utang bisa dipandang sebagai perusahaan yang yakin dengan prospek perusahaan dimasa mendatang. Namun disisi lain tingkat utang yang semakin tinggi berarti beban bunga perusahaan semakin besar dan akan mengurangi keuntungan perusahaan, tidak adanya pengaruh DER terhadap return saham dikarenakan sebagian investor hanya menganggap bahwa perusahaan yang memiliki prospek keberanian yang baik sajalah yang mampu menggunakan utang 
yang tinggi dalam struktur modalnya, dan penggunaan proporsi utang yang semakin tinggi akan menimbulkan resiko kebangkrutan.

Hasil penelitian ini bertentangan dengan penelitian yang dilakukan oleh Wingsih (2013) dan Septiana dan Wahyuati (2016) dengan hasil DER mempunyai pengaruh signifikan terhadap return saham. Penelitian ini mendukung penelitian yang dilakukan oleh (Supriyono, 2016).

\section{Beta dan Return Saham}

Hasil penelitian menunjukkan variabel Beta berpengaruh terhadap return saham. $\mathrm{Hal}$ ini mengindikasikan investor berharap untuk menerima keuntungan yang lebih tinggi untuk investasi berisiko dan lebih rendah untuk investasi yang lebih aman. Hasil ini mendukung penelitian (Supriyono, 2016). Selanjutnya Supriyono (2016) menyatakan bahwa investor cenderung berharap agar menerima keuntungan yang lebih tinggi untuk investasi yang berisiko dan lebih rendah untuk investasi yang lebih aman. Hasil ini mendukung penelitian (Supriyono, 2016).

Hal ini sejalan dengan Jogiyanto (2014) bahwa beta juga berfungsi sebagai pengukur volatilitas return saham atau portofolio terhadap return pasar. Volatilitas merupakan fluktuasi return suatu saham atau portofolio dalam suatu periode tertentu. Risiko yang relevan untuk dipertimbangkan dalam investasi yang berbentuk portofolio adalah risiko sistematis, dimana besar kecilnya risiko tersebut ditunjukkan oleh besar kecilnya satuan beta.

\section{Debt to Equity Ratio, Beta, dan Return Saham}

Hasil penelitian menunjukkan secara simultan DER dan Beta berpengaruh terhadao return saham. Hal ini terkait dengan ketika investor akan melakukan investasi, terdapat beberapa analisis yang akan dilakukan yaitu meniali resiko dan fundamental perusahaan. Ketika suatu perusahaan memiliki nilai DER yang tinggi dengan resiko Beta yang tinggi akan mempengaruhi keputusan investasi seorang investor terkait dengan return dari investasinya.

Nilai DER yang tinggi dapat saja merupakan bentuk keyakinan perusahaan untuk dapat berkembang menggunakan utang. Sehingga tidak akan berpengaruh terhadap return namun jika nilai DER yang tinggi dikaitkan dengan resiko perusahaan yang juga tinggi akan cenderung mempengaruhi return saham.

\section{PENUTUP}

Tujuan penelitian ini adalah menguji pengaruh DER dan Beta pada return saham perusahaan farmasi tercatat di BEI. Hasil penelitian menunjukkan bahwa $D E R$ tidak berpengaruh terhadap return saham dan risiko sistematis (beta) berpengaruh terhadap return saham pada perusahaan. DER tidak berpengaruh terhadap return saham dikarenakan sebagian investor hanya menganggap bahwa perusahaan yang memiliki kepercayaan diri yang baik sajalah yang mampu menggunakan utang yang tinggi dalam struktur modalnya. Penggunaan proporsi utang yang semakin tinggi akan cenderung menimbulkan risiko kebangkrutan.

Hipotesis kedua diterima, yang menunjukkan resiko berpengaruh terhadap return saham. Investor berharap untuk menerima keuntungan yang lebih tinggi untuk investasi berisiko dan lebih rendah untuk investasi yang lebih aman.

Implikasi penelitian ini adalah dalam melakukan pengambilan keputusan untuk investasi, investor harus mempertimbangkan mengenai analisa fundamental informasi keuangan dalam memperkirakan return saham yang akan diterima. Selain itu, para 
investor juga harus mempertimbangkan dan memperhatikan risiko-risiko yang akan diperoleh yang tentunya akan mempengaruhi return saham.

Dari hasil penelitian ini, perusahaan menunjukkan bahwa investor akan lebih mempertimbangkan faktor internal perusahaan dalam pengambilan keputusan untuk berinvestasi. Maka dari itu, sebaiknya perusahaan mampu membuat kebijakan yang tepat dalam meningkatkan kinerja perusahaan itu sendiri yang nantinya akan berdampak pada return saham yang tinggi.

Penelitian selanjutnya dapat menggunakan variabel lain diluar variabel DER maupun Beta saham untuk memperoleh hasil yang lebih signifikan seperti Earning per Share (EPS), Price Earning Ratio (PER) dan lain-lain. Selain itu, penelitian selanjutnya juga dapat menambah sampel penelitian dan periode pengamatan untuk membuktikan kembali hubungan variabel dalam penelitian ini.

\section{REFERENSI}

Arista, D. (2012). Analisis Faktor-Faktor yang Mempengaruhi Return Saham. Jurnal IImu Manajemen dan Akuntansi Terapan, 3(1), 1-15.

Arvirianty, A. (2017). Industri Farmasi Semakin Sehat. Media Indonesia [online]. Tersedia: www.mediaindonesia.com [Diakses 1 Oktober 2019]

Brealey, Richard A, dkk. (2001). Fundamentals of Corporate Finace. Third Edition. Singapore: Mc Graw-Hill.

Fahmi, I. (2012) . Analisis Kinerja Keuangan, Bandung: Alfabeta.

Husnan, Suad. (2005). Dasar-Dasar Teori Portofolio dan Analisis Sekuritas, Edisi keempat, Cetakan Pertama. Yogyakarta: UUP STIM YKPN.

Ismayanti, D. dan Wualnsari, M. (2014). Pengaruh Faktor Fundamental Dan Risiko (Beta) Terhadap Return Saham Pada Perusahaan Yang Termasuk
Dalam Indeks LQ 45. JWM (Jurnal Wawasan Manajemen), 2(1), 1-20. http://dx.doi.org/10.20527/jwm.v2i1. 30

Jogiyanto. (2014). Teori Portofolio dan Analisis Investasi. Edisi Tiga. Yogyakarta: BPFE

Jones, Charles P.(2000). Investment: Analysis and Management, 7th edition, New York: John Willey and Sons.Inc.

Prasetyo, dkk. (2012). Pengaruh Faktor Fundamental Dan Risiko Sistematis Terhadap Return Saham Syariah. Media Riset Akuntansi, Auditing Dan Informasi, 12(1), 23-44. http://dx.doi.org/10.25105/mraai.v12i 1.581

Ross, A.S, dkk. (2003). Fundamentals of Corporate Finance. Sixth edition. New York: Mc Graw-Hill.

Sartono, A. (2001). Manajemen Keuangan Teori dan Aplikasi. Yogyakarta: BPEFYogyakarta.

Scott, Besley., Eugene F, Bringham. (2000). Essentials of Managerial Finance, Twelfth Edition. Orlando: Harcourt Inc.

Septiana, F dan Wahyuati, A. (2016). Pengaruh Rasio Keuangan Terhadap Return Saham Pada Perusahaan Manufaktur. Jurnal IImu dan Riset Manajemen. 5(1), 1-21.

Sudarto, Krisnhoe, F, dan Tohir, R. (1999). Analisis Return Saham dan Faktor faktor yang Mempengaruhinya, JEBA, $1(1), 43-51$.

Suharli, M. (2005). Akuntansi untuk Bisnis Jasa dan Dagang. Edisi Pertama, Yogyakarta: Graha IImu.

Supriyono, E.(2016). Pengaruh Debt to Equity Ratio, Return on Asset, BETA dan KURS terhadap Return Saham. Tesis. Universitas Muhammadiyyah Yogyakarta.

Tandelilin, E. (2001). Analisis Investasi Manajemen Portfolio, Cetakan Pertama, Yogyakarta: BPFE. 
JIAFE (Jurnal Ilmiah Akuntansi Fakultas Ekonomi)

Vol. 6 No. 1, Juni 2020, Hal. 83-92

https://journal.unpak.ac.id/index.php/jiafe

P-ISSN: 2502-3020, E-ISSN: 2502-4159

Wingsih, Y. (2013). Analisis Pengaruh Likuiditas, Profitabilitas, dan

Pekanbaru Terhadap Tingkat

Keuntungan dalam Sektor Properti Solvabilitas Terhadap Return Saham Pada Perusahaan Pertambangan Yang Terdaftar di Bursa Efek Indonesia Pada dan Real Estate di BEJ. Jurnal Penelitian Riset Akuntansi IX, Fakultas Ekonomi.

Tahun 2008 Sampai 2012. Skripsi.

Universitas Dian Nuswantoro.

Yunina, F., dkk. (2013). Pengaruh Risiko Sistematik, Leverage dan Laba Terhadap Return Saham. Jurnal Akuntansi Pascasarjana Universitas Syiah Kuala, 2(2), 56-64.

Zulbahridar dan Jonius. (2002). Pengaruh Risiko dan Leverage Keuangan Riau- 
